\title{
The Distribution of the Dissolved and the Particulate Carbohydrates in the Kuroshio and its Adjacent Areas*
}

\author{
Nobuhiko HANDA**
}

\begin{abstract}
At 31 stations in the areas surrounding Nansei Shoto and Izu Shoto and the areas in which JEDSi-4 (1961) and JEDS-5 (1962) were carried out, samples were collected at different levels down to $5,610 \mathrm{~m}$ in which concentrations of the dissolved and the particulate carbohydrates were determined with the following results. a) The dissolved carbohydrate showed some regional difference in concentration in the surface and subsurface layers. b) The concentration of the dissolved carbohydrate is rather uniform vertically from the surface to about $1,000 \mathrm{~m}$ depth, below which there is a tendency of a slight decrease. d) The concentration of the particulate carbohydrate is higher in the surface and subsurface layers and decrease to $10 \mu \mathrm{g} / l$ at $500 \mathrm{~m}$ depth. There is no significant difference among different regions. d) The concentration of the dissolved carbohydrate in sea water is always higher than that of the particulate carbodydrate. The ratio of the former to the latter varies from about 10 at upper layers to 35 or even higher values at deep layers.

Using the present and the previous data obtained by the present author and other investigators, relationships between the particulate and the dissolved carbohydrates and factors affecting the relationships are discussed.
\end{abstract}

\section{Introduction}

The distributions of the dissolved carbohydrate were studied in the Gulf of Mexico, the South Atlantic Ocean and the Eastern Pacific Ocean by WANGERSKY (1952), COLLIER et al. (1953), ANDERSON et al. (1958), LEWIS and RAKESTRAW (1955) and ANTIA et al. (1963). Recently the present author (1966) gave the concentration of the dissolved carbohydrate of $0.21-0.39 \mathrm{mg} / \mathrm{l}$ and $0.19-0.66 \mathrm{mg} / l$ in the upper layer and waters below $100 \mathrm{~m}$ in the tropical and the subtropical areas in the eastern part of the Indian Ocean.

In addition to the dissolved carbohydrate, it is nezessary to investigate the particulate carbohydrate in suspended particulates, particularly in plankton cells and their debris which are regarded to be the source of the dissolved carbohydrate.

MENZEL (1964) determined the contents of the dissolved organic carbon and the particulate

\footnotetext{
* Received Jan. 9, 1967

** Water Research Laboratory, Faculty of Science, Nagoya University

$\uparrow$ The abbreviation of the Japanese Expedition of Deep Sea.
}

organic carbon in samples collected from the surface to $3,200 \mathrm{~m}$ depth in the Arabian Sea. $\mathrm{He}$ reported that the concentration of the dissolved organic carbon is ten times that of the particulate organic carbon. In the present paper the author intends to report the results of his determination of both the dissolved and the particulate carbohydrates in sea water samples collected at two different areas of the Kuroshio surrounding Nansei Shoto and Izu Shoto and will discuss the relationships between the dissolved and the particulate carbohydrates.

\section{The method of determination of carbohydrate}

Determination of the dissolved carbohydrate

The water sample collected by the Nansen bottle was filtered through a Millipore filter (HA) and was stored in a deep freezer. The dissolved carbohydrate in the stored sample was analysed by the phenol sulfuric acid method as described in the previous paper (HANDA, 1966). The concentration of the dissolved carbohydrate obtained was expressed in terms of D-glucose equivalent.

The determination of the particulate carbohydrate 
116

Jour. Oceanogr. Soc. Japan, Vol. 23, No. 3 (1967)

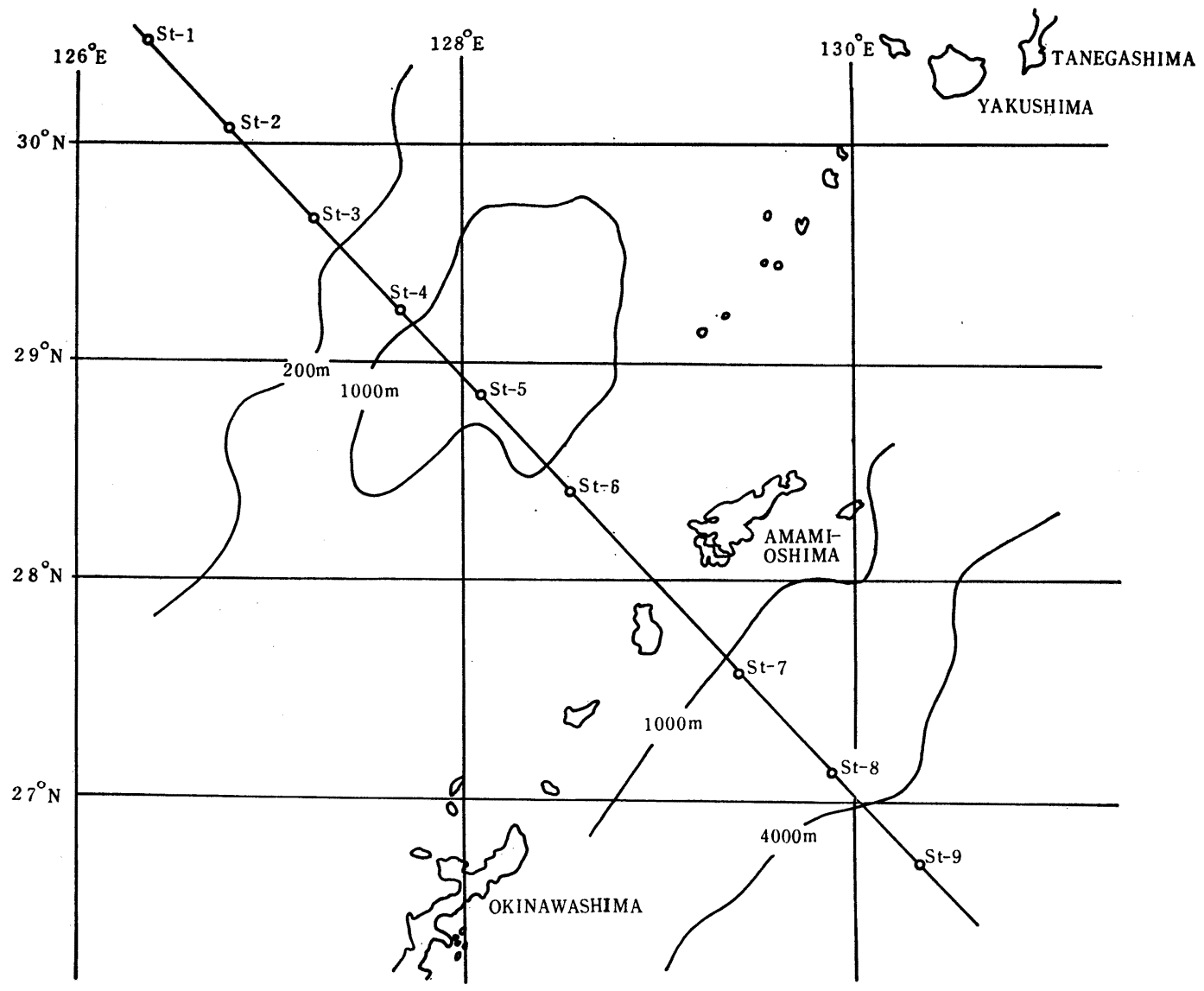

Fig. 1. Location of sampling stations in the Nansen Shote area (May 25-June 7, 1965).

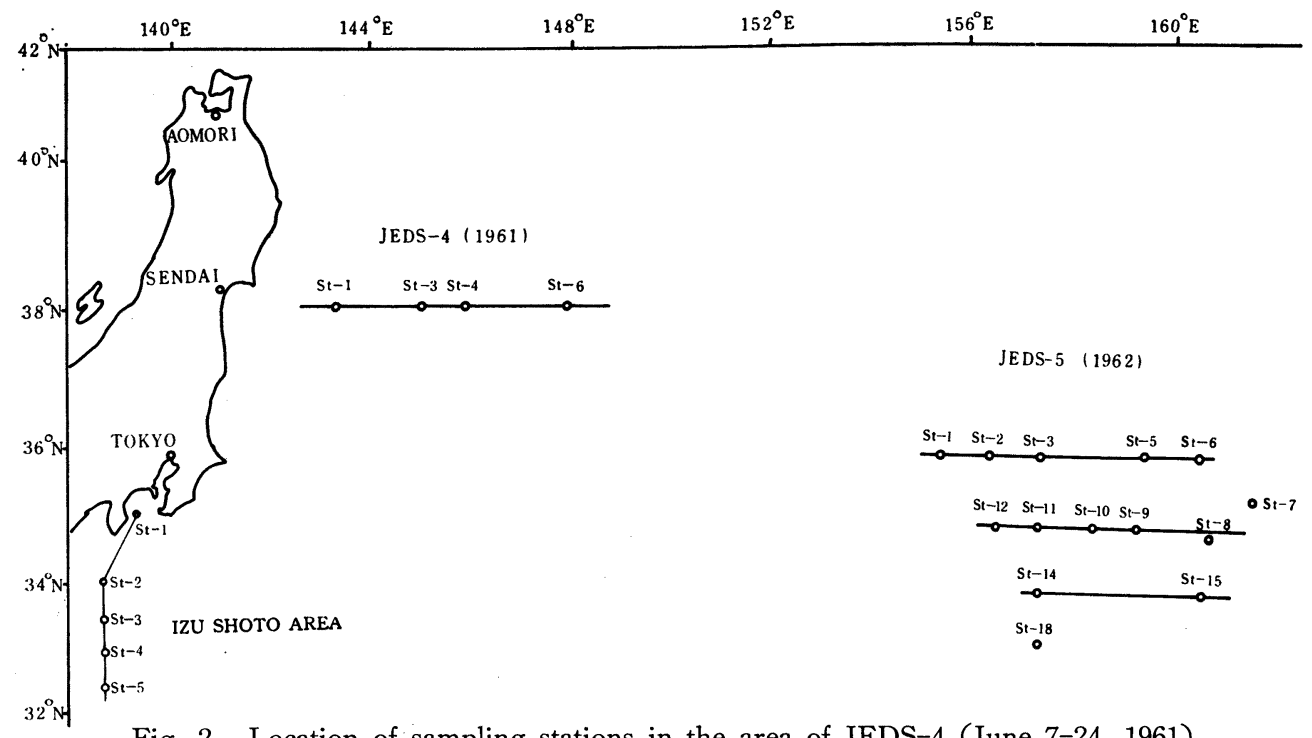

Fig. 2. Location of sampling stations in the area of JEDS-4 (June 7-24, 1961) and JEDS-5 (May 12-18, 1962), and Itu Shoo area (May 5-11, 1965).

(2) 
in the Kuroshio and its Adjacent Areas

About $10 l$ of a sea water sample was filtered by suction through a glass fiber filter with a porosity of $c a 1 \mu$ and $4.7 \mathrm{~cm}$ in a diameter. Immediately after the filtration the glass fiber filter was kept in a deep freezer. Before the phenol sulfuric acid treatment was done, the stored sample on the glass fiber filter was treated with $1 \mathrm{~m} l$ fuming hydrochloric acid for 5 minutes at $5^{\circ} \mathrm{C}$ to hydrolyze insoluble polysaccharide. The digest was transferred with $14 \mathrm{~m} l$ water

Table 1. Concentrations of the dissolved and the particulate carbohydrates in the Kuroshio (Nansei Shoto area).

\begin{tabular}{|c|c|c|c|c|c|c|c|c|c|c|c|c|}
\hline \multirow{2}{*}{$\begin{array}{l}\text { Depth } \\
(\mathrm{m})\end{array}$} & \multicolumn{4}{|c|}{ Station 1} & \multicolumn{4}{|c|}{ Station 2} & \multicolumn{4}{|c|}{ Station 3} \\
\hline & $\begin{array}{c}\mathrm{a} \\
\mathrm{mg} / l\end{array}$ & $\begin{array}{c}\mathrm{b} \\
\mu_{\mathrm{g} / l}\end{array}$ & $a / b$ & $\begin{array}{l}\text { Temp. } \\
\left({ }^{\circ} \mathrm{C}\right)\end{array}$ & $\begin{array}{c}\mathrm{a} \\
\mathrm{mg} / l\end{array}$ & $\begin{array}{c}\mathrm{b} \\
\mu_{\mathrm{g} / l}\end{array}$ & $a / b$ & $\begin{array}{c}\text { Temp. } \\
\left({ }^{\circ} \mathrm{C}\right)\end{array}$ & $\mathrm{a}$ & $\begin{array}{c}\mathrm{b} \\
\mu_{\mathrm{g} / l}\end{array}$ & $a / b$ & $\begin{array}{c}\text { Temp. } \\
\left({ }^{\circ} \mathrm{C}\right)\end{array}$ \\
\hline 0 & 0.32 & 25.9 & 12.4 & 17.6 & 0.41 & 27.5 & 14.9 & 19.4 & 0.41 & 18.5 & 21.0 & 22.3 \\
\hline 20 & 0.35 & 29.3 & 11.9 & 14.3 & 0.35 & 30.0 & 11.6 & 19.3 & 0.38 & 19.6 & 19.3 & 22.3 \\
\hline 50 & 0.34 & 29.3 & 11.4 & 12.5 & 0.32 & 29.5 & 10.8 & 17.4 & 0.33 & 20.8 & 15.8 & 19.3 \\
\hline 75 & 0.32 & 27.0 & 11.7 & 12.7 & 0.41 & 29.3 & 14.9 & 17.4 & 0.35 & 22.1 & 15.8 & 18.2 \\
\hline 100 & & & & & & & & & 0.33 & 17.1 & 19.2 & 18.2 \\
\hline \multicolumn{13}{|l|}{ Average } \\
\hline & 0.33 & & & & 0.39 & & & & 0.36 & & & \\
\hline$\because$ & \multicolumn{4}{|c|}{ Station 4} & \multicolumn{4}{|c|}{ Station 5} & \multicolumn{4}{|c|}{ Station 6} \\
\hline (m) & $\mathrm{a}$ & $\begin{array}{c}\mathrm{b} \\
\mu_{\mathrm{g} / l}\end{array}$ & $a / b$ & $\begin{array}{l}\text { Temp. } \\
\left({ }^{\circ} \mathrm{C}\right)\end{array}$ & $\begin{array}{c}\mathrm{a} \\
\mathrm{mg} / l\end{array}$ & $\begin{array}{c}\mathrm{b} \\
\mu_{\mathrm{g} / l}\end{array}$ & $a / b$ & $\begin{array}{c}\text { Temp. } \\
\left({ }^{\circ} \mathrm{C}\right)\end{array}$ & $\mathrm{a}$ & $\begin{array}{c}\mathrm{b} \\
\mu_{\mathrm{g}} / l\end{array}$ & $a / b$ & $\begin{array}{c}\text { Temp. } \\
\left({ }^{\circ} \mathrm{C}\right)\end{array}$ \\
\hline 0 & 0.33 & & & 23.6 & 0.39 & & & 25.5 & 0.36 & & & 22.3 \\
\hline 20 & 0.34 & 18.6 & 18.2 & 23.5 & 0.31 & 15.7 & 19.7 & 25.4 & 0.27 & 18.3 & 16.1 & 22.4 \\
\hline 50 & 0.36 & 18.9 & 19.0 & 22.7 & 0.25 & 17.2 & 14.5 & 25.0 & 0.33 & 19.9 & 16.5 & 21.4 \\
\hline 75 & 0.35 & 16.1 & 22.3 & 21.6 & 0.31 & 17.1 & 18.1 & 23.5 & 0.32 & 17.0 & 18.8 & 21.0 \\
\hline 100 & 0.33 & 16.1 & 21.2 & 18.9 & 0.32 & 12.7 & 25.2 & 22.5 & 0.41 & 13.4 & 30.3 & 20.6 \\
\hline 125 & 0.29 & 12.1 & 24.0 & 16.8 & 0.23 & 12.2 & 18.8 & 22.1 & 0.34 & 12.5 & 27.2 & 20.2 \\
\hline 150 & 0.29 & 11.4 & 25.2 & 15.5 & 0.27 & 12.0 & 22.1 & 21.4 & 0.28 & 11.9 & 23.3 & 20.1 \\
\hline 200 & 0.30 & 10.6 & 28.2 & 13.5 & 0.39 & 11.4 & 34.2 & 20.9 & 0.36 & 10.6 & 34.0 & 19.6 \\
\hline 500 & 0.35 & 11.6 & 30.1 & 10.4 & 0.36 & 10.2 & 35.6 & 13.4 & 0.38 & 10.3 & 36.7 & 13.8 \\
\hline 1000 & & & & & 0.35 & 10.6 & 34.0 & 8.9 & & 10.6 & & \\
\hline \multirow[t]{2}{*}{ Average } & & & & & & & & & & & & \\
\hline & 0.32 & & & & 0.31 & & & & 0.34 & & & \\
\hline & \multicolumn{4}{|c|}{ Station 7} & \multicolumn{4}{|c|}{ Station 8} & \multicolumn{4}{|c|}{ Station 9} \\
\hline (m) & $\begin{array}{c}\mathrm{a} \\
\mathrm{mg} / l\end{array}$ & $\begin{array}{c}\mathrm{b} \\
\mu_{\mathrm{g} / l}\end{array}$ & $a / b$ & $\begin{array}{l}\text { Temp. } \\
\left({ }^{\circ} \mathrm{C}\right)\end{array}$ & $\begin{array}{c}\mathrm{a} \\
\mu_{\mathrm{g} / l}\end{array}$ & $\begin{array}{c}\mathrm{b} \\
\mu_{\mathrm{g} / l}\end{array}$ & $a / b$ & $\begin{array}{c}\text { Temp. } \\
\left({ }^{\circ} \mathrm{C}\right)\end{array}$ & $\begin{array}{c}\mathrm{a} \\
\mathrm{mg} / l\end{array}$ & $\begin{array}{c}\mathrm{b} \\
\mu_{\mathrm{g} / l}\end{array}$ & $a / b$ & $\begin{array}{l}\text { Temp. } \\
\left({ }^{\circ} \mathrm{C}\right)\end{array}$ \\
\hline 0 & 0.34 & & & 24.0 & 0.42 & & & 25.0 & 0.28 & & & 24.8 \\
\hline 20 & 0.23 & 19.4 & 11.8 & 22.5 & 0.31 & 16.5 & 18.7 & 24.7 & 0.33 & 17.2 & 19.2 & 24.2 \\
\hline 50 & 0.31 & 19.1 & 16.2 & 20.9 & 0.32 & 17.1 & 18.7 & 22.0 & 0.23 & 17.9 & 12.8 & 21.5 \\
\hline 75 & 0.31 & 15.8 & 19.6 & 20.1 & 0.38 & 14.8 & 25.6 & 21.3 & 0.23 & 15.2 & 15.1 & 20.7 \\
\hline 100 & 0.40 & 12.9 & 31.0 & 19.5 & 0.31 & 12.0 & 25.8 & 20.2 & 0.29 & 12.9 & 22.4 & 20.0 \\
\hline 125 & 0.31 & 9.8 & 31.8 & 19.2 & 0.42 & 11.9 & 35.3 & 19.9 & 0.34 & 12.9 & 26.4 & 19.7 \\
\hline 150 & 0.33 & 10.2 & 30.6 & 18.7 & 0.35 & 11.1 & 28.8 & 19.3 & 0.38 & 12.3 & 30.9 & 18.9 \\
\hline 200 & 0.44 & & & 18.1 & 0.21 & 10.9 & 18.2 & 19.5 & 0.33 & 11.0 & 30.0 & 18.4 \\
\hline 500 & 0.32 & 13.2 & 24.1 & 12.5 & 0.33 & 10.8 & 30.6 & 13.2 & 0.44 & 11.4 & 37.7 & 13.2 \\
\hline 1000 & 0.36 & & & 7.3 & 0.29 & 10.2 & 28.4 & 9.0 & 0.28 & 10.8 & 25.9 & 7.5 \\
\hline Average & 0.33 & & & & 0.32 & & & & 0.31 & & & \\
\hline
\end{tabular}

a : dissolved carbohydrate

b : particulate carbohydrate 
Table 2. Concentrations of the dissolved and the particulate carbohydrates in the Kuroshio (Izu Shoto area).

\begin{tabular}{|c|c|c|c|c|c|c|c|c|c|c|c|c|}
\hline \multirow{2}{*}{$\begin{array}{l}\text { Depth } \\
(\mathrm{m})\end{array}$} & \multicolumn{3}{|c|}{ Station 1} & \multicolumn{3}{|c|}{ Station 3} & \multicolumn{3}{|c|}{ Station 4} & \multicolumn{3}{|c|}{ Station 5} \\
\hline & $\begin{array}{c}\mathrm{a} \\
\mathrm{mg} / l\end{array}$ & $\begin{array}{c}\mathbf{b} \\
\mu_{\mathrm{g} / l}\end{array}$ & $a / b$ & $\begin{array}{c}\mathrm{a} \\
\mathrm{mg} / l\end{array}$ & $\begin{array}{c}\mathrm{b} \\
\mu_{\mathrm{g} / l}\end{array}$ & $a / b$ & $\begin{array}{c}\mathrm{a} \\
\mathrm{mg} / l\end{array}$ & $\begin{array}{c}\mathrm{b} \\
\mu_{\mathrm{g} / l}\end{array}$ & $a / b$ & $\begin{array}{c}\mathrm{a} \\
\mathrm{mg} / \mathrm{l}\end{array}$ & $\begin{array}{c}\mathrm{b} \\
\mu_{\mathrm{g} / l} / l\end{array}$ & $a / b$ \\
\hline 0 & 0.33 & 28.8 & 11.5 & 0.40 & 15.6 & 25.6 & 0.41 & 15.3 & 26.8 & 0.32 & 13.0 & 17.8 \\
\hline 20 & 0.36 & 33.9 & 10.6 & 0.30 & 20.5 & 14.6 & & 16.4 & & & & \\
\hline 50 & 0.46 & 26.0 & 17.7 & 0.31 & 14.4 & 21.2 & 0.31 & 14.4 & 20.8 & 0.30 & 18.0 & 16.7 \\
\hline 100 & 0.28 & 15.6 & 17.9 & 0.35 & 12.0 & 29.1 & 0.28 & 9.9 & 28.3 & 0.28 & & \\
\hline 200 & 0.32 & 10.4 & 30.4 & 0.25 & 10.5 & 24.3 & 0.36 & 10.6 & 28.3 & 0.38 & & \\
\hline 500 & 0.32 & 10.7 & 29.9 & 0.26 & 10.7 & 24.3 & & 10.8 & & 0.30 & & \\
\hline \multicolumn{13}{|c|}{ Average } \\
\hline & 0.34 & & & 0.31 & & & 0.34 & & & 0.31 & & \\
\hline
\end{tabular}

a: dissolved carbohydrate

b : particulate carbohydrate

into a tube. After the tube was sealed the solution was heated for 24 hours at $100^{\circ} \mathrm{C}$ to complete hydrolysis*. Then the aliquot of the hydrolysate was subjected to the phenol sulfuric acid treatment.

\section{The sampling stations}

Sampling station were shown in Figs. 1 and 2. In the Nansei Shoto area, the distribution of water temperature showed that the stations 4 through 9 were located in the Kuroshio with the axis at around station 5 , while the stations 1 to 3 were in the outside of the current.

In the Izu Shoto area all stations were located in the Kuroshio except station 1 in Sagami Bay.

All four stations along $35^{\circ} \mathrm{N}$ between $143^{\circ}-$ $148^{\circ} \mathrm{E}$ were situated in the boundary region between the Kuroshio and the Oyashio waters according to the hydrographic observation (MASUZAWA, 1962). JEDS-5 stations in the area, $34^{\circ}-36^{\circ} \mathrm{N}$ and $156^{\circ}-162^{\circ} \mathrm{E}$ were situated in the extention of the Kuroshio.

\section{Results and discussion}

The observed concentrations of the dissolved and the particulate carbohydrates are listed in Tables 1 to 5 .

* This hydrolytic pretreatment is necessary because the sample contained insoluble polysaccharides such as cellulose. The experiments by using cotton and wood cellulose proved the present procedure was quite satisfactory to recorver more than $95 \%$ of D-glucose in cellulose susceptible to the phenol sulfuric acid method.
1) The Nansei Shoto area

In this area the distributions of both the dissolved and the particulate carbohydrate were found to be rather uniform horizontally and vertically with the values ranging from 0.23 to $0.44 \mathrm{mg} / l$, while the considerable variation in the distribution of the particulate carbohydrate was observed. Thus as shown in Fig. 3, the particulate carbohydrate was rather high with values ranging 27 to $30 \mu \mathrm{g} / l$ at stations 1 and 2 , while it was low at stations 4 through 9 with values of $15-19 \mu \mathrm{g} / l$ from the surface to the $75 \mathrm{~m}$ depth. The difference in the horizontal distribution seems to be parallel to the distribution of chlorophyll $a$. SAIJO observed that the concentration of chlorophyll $a$ was high with values of $0.11-0.20 \mathrm{mg} / \mathrm{m}^{3}$ at the station 1 , while it was low at stations 5 and 9, 0.03$0.17 \mathrm{mg} / \mathrm{m}^{3}$ and $0.02-0.08 \mathrm{mg} / \mathrm{m}^{3}$ respectively. The above results can be explained as follows. In comparison with the stations in the Kuroshio, at stations 1 and 2 located on the continental shelf a higher production of planktonic biomass which brings about a high content of chlorophyll $a$ in waters causes the observed enrichment of the particulate carbohydrate there. At stations 4 to 9 , the carbohydrate content is rather uniform from the surface down to the $75 \mathrm{~m}$ level, below which it decreases rather sharply down to $150 \mathrm{~m}$ depth. The rate of decrease was small below this level reaching values about $10 \mu \mathrm{g} / l$ at levels 500 to $1,000 \mathrm{~m}$.

2) The Izu Shoto area

The distribution of the dissolved and the 
The Distribution of the Dissolved and the Particulate Carbohydrates in the Kuroshio and its Adjacent Areas

Table 3. Concentration of the dissolved carbohydrate (JEDS-4 area).

\begin{tabular}{|c|c|c|c|c|c|c|c|c|c|}
\hline \multicolumn{2}{|c|}{ Station 1} & \multicolumn{2}{|c|}{ Station 3} & \multicolumn{2}{|c|}{ Station 4} & \multicolumn{4}{|c|}{ Station 6} \\
\hline $\begin{array}{c}\text { Depth } 1 \\
\text { (m) }\end{array}$ & $\begin{array}{c}38^{\circ} 04^{\prime} \mathrm{N} \\
143019^{\prime} \mathrm{E} \\
\mathrm{mg} / l\end{array}$ & $\begin{array}{c}\text { Depth } \\
\text { (m) }\end{array}$ & $\begin{array}{r}37^{\circ} 57^{\prime} \mathrm{N} \\
144^{\circ} 51^{\prime} \mathrm{E} \\
\mathrm{mg} / l\end{array}$ & $\begin{array}{l}\text { Depth } \\
\text { (m) }\end{array}$ & $\begin{array}{r}38^{\circ} 01^{\prime} \mathrm{N} \\
148^{\circ} 00^{\prime} \mathrm{E} \\
\mathrm{mg} / l\end{array}$ & $\begin{array}{c}\text { Depth } \\
(\mathrm{m})\end{array}$ & $\begin{array}{c}38^{\circ} 01^{\prime} \mathrm{N} \\
148^{\circ} 00^{\prime} \mathrm{E} \\
\mathrm{mg} / \mathrm{l}\end{array}$ & $\begin{array}{l}\text { Depth } \\
\text { (m) }\end{array}$ & $\begin{array}{r}38^{\circ} 01^{\prime} \mathrm{N} \\
148^{\circ} 00^{\prime} \mathrm{E} \\
\mathrm{mg} / \mathrm{l}\end{array}$ \\
\hline 0 & 0.28 & 0 & 0.39 & 0 & 0.18 & 0 & 0.29 & 1225 & 0.24 \\
\hline 20 & 0.33 & 20 & 0.21 & 20 & .029 & 10 & 0.30 & 1472 & 0.33 \\
\hline 50 & 0.31 & 50 & 0.28 & 50 & 0.26 & 20 & 0.29 & 1895 & 0.34 \\
\hline 100 & 0.31 & 100 & 0.27 & 100 & 0.19 & 30 & 0.22 & 2143 & 0.21 \\
\hline 199 & 0.34 & 193 & 0.27 & 197 & 0.29 & 50 & 0.20 & 2391 & 0.27 \\
\hline 395 & 0.29 & 387 & - & 395 & 0.29 & 75 & 0.27 & 2641 & 0.36 \\
\hline 580 & 0.29 & 579 & 0.34 & 593 & 0.34 & 100 & 0.34 & 2892 & 0.36 \\
\hline 753 & 0.16 & 769 & 0.36 & 791 & 0.14 & 146 & 0.19 & 3138 & 0.27 \\
\hline 937 & 0.39 & 958 & 0.39 & 988 & 0.14 & 195 & 0.24 & 3236 & 0.27 \\
\hline 1354 & 0.14 & 1433 & 0.24 & & & 293 & 0.34 & 3486 & 0.33 \\
\hline 1808 & 0.21 & 1874 & 0.32 & & & 391 & 0.28 & 3735 & 0.35 \\
\hline 2308 & 0.34 & 2357 & 0.29 & & & 489 & 0.30 & 3985 & 0.18 \\
\hline \multirow[t]{3}{*}{2778} & 0.31 & 3509 & 0.29 & & & 588 & 0.31 & 4610 & 0.13 \\
\hline & & 3600 & 0.15 & & & 783 & 0.21 & 5110 & 0.36 \\
\hline & & 980 & 0.24 & & & 980 & 0.24 & 5610 & 0.26 \\
\hline \multicolumn{10}{|l|}{ Average } \\
\hline 0-937 & 0.30 & $0-958$ & 0.31 & $0-988$ & 0.24 & & & 0-980 & 0.27 \\
\hline $1354-2778$ & $\begin{array}{ll}8 & 0.25\end{array}$ & $1473-3600$ & $0 \quad 0.26$ & & & & & $1225-5610$ & $\begin{array}{ll}0 & 0.28\end{array}$ \\
\hline
\end{tabular}

Table 4. Concentration of the dissolved carbohydrate (JEDS-5 area).

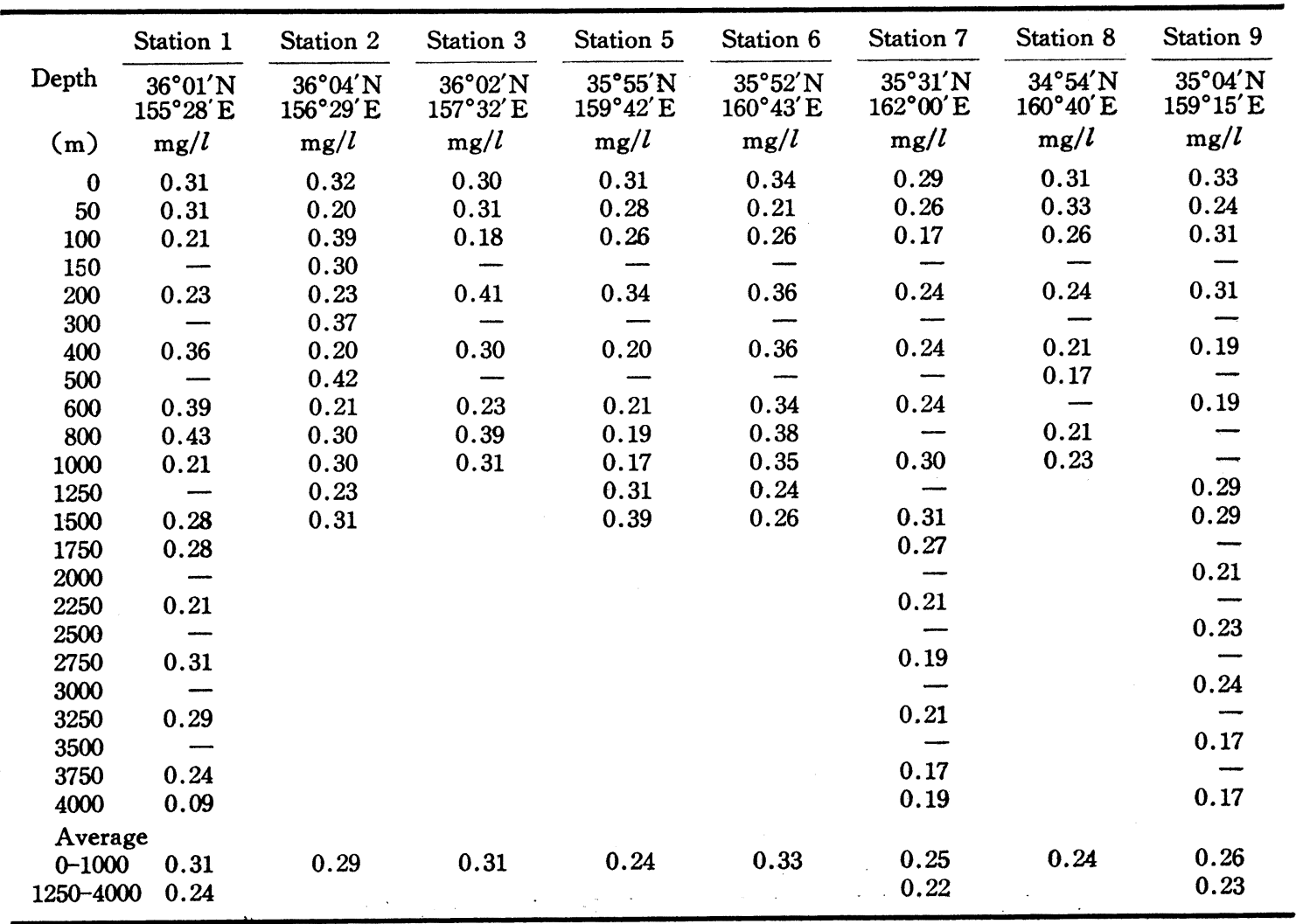


Table 5. Concentration of the dissolved carbohydrate (JEDS-5 area).

\begin{tabular}{|c|c|c|c|c|c|c|}
\hline & Station 10 & Station 11 & Station 12 & Station 14 & Station 15 & Station 18 \\
\hline Depth & $\begin{array}{r}35^{\circ} 00^{\prime} \mathrm{N} \\
158^{\circ} 13^{\prime} \mathrm{E}\end{array}$ & $\begin{array}{r}34^{\circ} 58^{\prime} \mathrm{N} \\
157^{\circ} 26^{\prime} \mathrm{E}\end{array}$ & $\begin{array}{r}35^{\circ} 03^{\prime} \mathrm{N} \\
156^{\circ} 24^{\prime} \mathrm{E}\end{array}$ & $\begin{array}{r}33^{\circ} 14^{\prime} \mathrm{N} \\
157^{\circ} 32^{\prime} \mathrm{E}\end{array}$ & $\begin{array}{r}34^{\circ} 14^{\prime} \mathrm{N} \\
157^{\circ} 21^{\prime} \mathrm{E}\end{array}$ & $\begin{array}{r}33^{\circ} 55^{\prime} \mathrm{N} \\
160^{\circ} 20^{\prime} \mathrm{E}\end{array}$ \\
\hline$(\mathrm{m})$ & $\mathrm{mg} / l$ & $\mathrm{mg} / l$ & $\mathrm{mg} / \mathrm{l}$ & $\mathrm{mg} / \mathrm{l}$ & $\mathrm{mg} / \mathrm{l}$ & $\mathrm{mg} / \mathrm{l}$ \\
\hline 0 & 0.29 & - & 0.23 & 0.21 & 0.31 & 0.17 \\
\hline 50 & 0.29 & 0.27 & 0.31 & 0.29 & 0.26 & 0.31 \\
\hline 100 & 0.21 & 0.33 & - & - & - & - \\
\hline 200 & 0.24 & 0.21 & 0.24 & 0.31 & - & - \\
\hline 400 & 0.31 & 0.21 & 0.26 & 0.24 & 0.24 & 0.27 \\
\hline 600 & 0.34 & 0.29 & 0.31 & 0.19 & - & \\
\hline 800 & 0.36 & 0.29 & 0.21 & 0.27 & 0.21 & \\
\hline 1000 & 0.31 & 0.27 & 0.21 & 0.21 & 0.28 & \\
\hline 1250 & 0.26 & 0.21 & 0.17 & 0.21 & 0.24 & \\
\hline 1500 & 0.27 & 0.24 & 0.21 & - & & \\
\hline 1750 & - & - & - & 0.17 & & \\
\hline 2000 & 0.27 & 0.24 & 0.28 & - & & \\
\hline 2250 & - & - & - & 0.21 & & \\
\hline 2500 & 0.17 & 0.14 & 0.28 & - & & \\
\hline 2750 & - & - & - & 0.17 & & \\
\hline 3000 & 0.21 & 0.21 & 0.24 & - & & \\
\hline 3250 & - & - & - & 0.14 & & \\
\hline 3500 & 0.21 & 0.16 & 0.11 & & & \\
\hline 3750 & & - & - & & & \\
\hline 4000 & 0.19 & & 0.19 & & & \\
\hline Average & & & & & & \\
\hline $0-1000$ & 0.29 & 0.27 & 0.25 & 0.25 & 0.26 & 0.25 \\
\hline $1250-4000$ & 0.23 & 0.20 & 0.21 & 0.18 & & \\
\hline
\end{tabular}

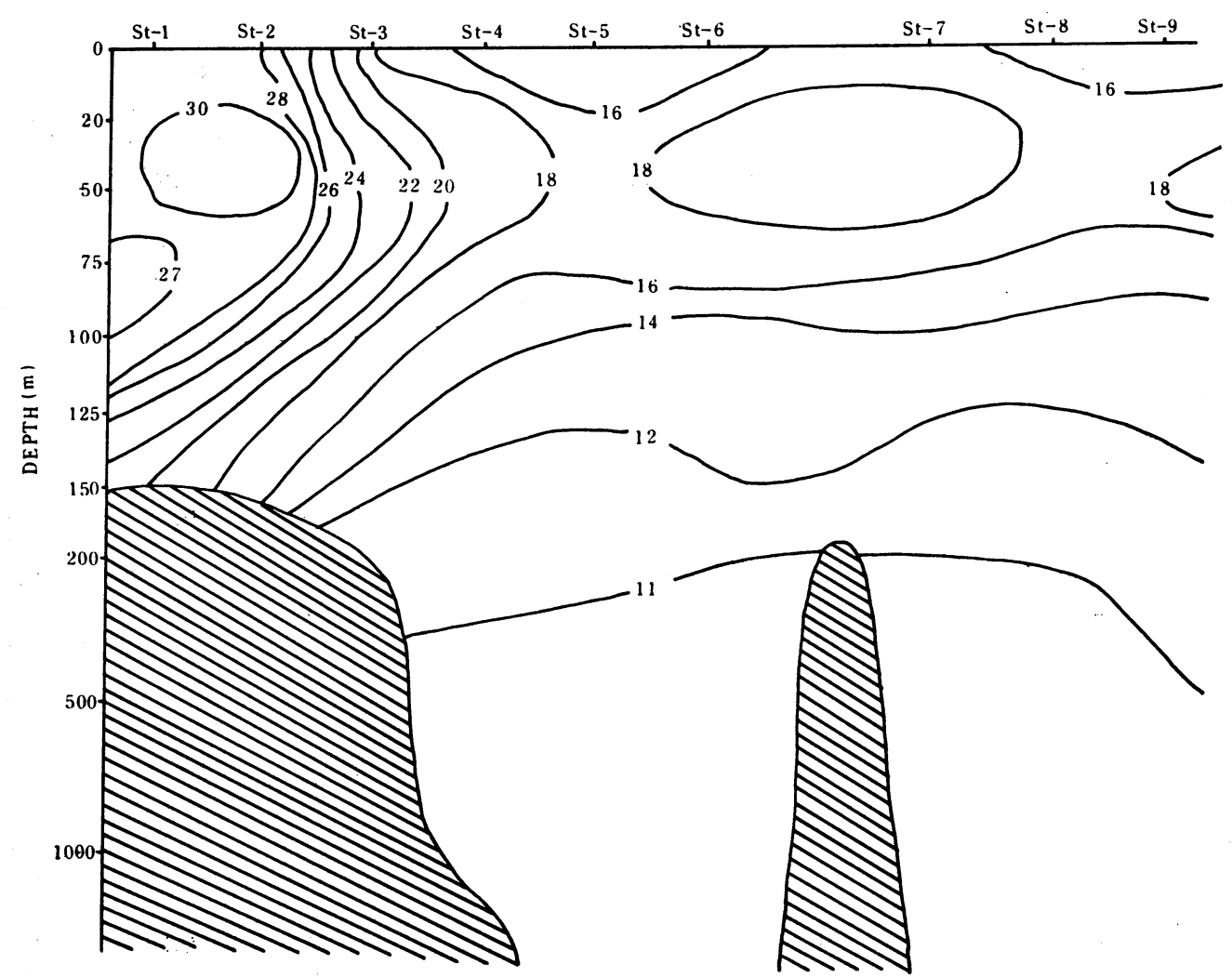

Fig. 3. Distribution of the particulate carbohydrate in the Nansei Shoto area. 
particulate carbohydrates in this area was similar to that in the Nansei Shoto area. The dissolved carbohydrate was uniformly distributed horizontally and verticaly with values of $0.28-0.46$ $\mathrm{mg} / l$. The distribution of the particulate carbo. hydrate varies from region to region. It was higher at the station 1 in Sagami Bay with values of $26-34 \mu \mathrm{g} / l$ from the surface to a $50 \mathrm{~m}$ depth, while at the stations from 3 to 5 in the Kuroshio it was lower with values of $13-21 \mu \mathrm{g} / l$. The trend of decrease in the particulate carbohydrate with depth as seen in the Nansei Shoto area was confirmed here by the fact that the concentration of the particulate carbohydrate varied from $20-30 \mu \mathrm{g} / l$ in the surface and the subsurface waters to about $10 \mu \mathrm{g} / l$ at $500 \mathrm{~m}$ depth.

3) Off North-eastern Honshu

The concentration of the dissolved carbohydrate ranged $0.09-0.43 \mathrm{mg} / l$ and $0.11-0.26$ $\mathrm{mg} / l$ at four stations in JEDS-4 (1961) and fourteen stations in JEDS-5 (1962). The distribution of the dissolved carbohydrate was uniform down to $1,000 \mathrm{~m}$ depth as observed in the areas of the Nansei Shoto and the Izu Shoto. Different from these areas however, so far as the content of the dissolved carbohydrate layers deeper than $1,000 \mathrm{~m}$ seemed to constitute a separate zone where the concentration of carbohydrate was distinctively smaller than that in overlying levels.

Summarising the present results, the concentration of the dissolved carbohydrate in the sea areas mentioned above ranges $0.09-0.46 \mathrm{mg} / l$. The values are almost comparable to those in he tropical and the subtropical areas of the Indian Ocean, $0.19-0.66 \mathrm{mg} / l$ observed by the present author and the results of observation on the total carbohydrate in the eastern Pacific Ocean by LEWIS and RAKESTRAW in 1955, $0.14-0.46 \mathrm{mg} / l$. This indicates that there is no significant difference in the concentration of the dissolved carbohydrate in the surface to a $1,000 \mathrm{~m}$ depth with a slight tendency of decrease in the concentration below this level. This distribution of the particulate carbohydrate showed some regional difference. As stated above, it was higher in waters above the continental shelf and in Sagami Bay. However, this regional difference is limited to the surface and subsurface layers and the values of the particulate carbohydrate in deeper layers were found to be rather uniform irrespective of region.

The results of the present observations can be explained as follows: The particulate carbohydrate is a constituent in plankton cells and their debris. Accordingly, its concentration is high in sea areas where the production of plankton is high. On the other hand, the dissolved carbohydrate is regarded to be a product excreted from living plankton bodies or a product in decay process of planktonic cells. It is to be noticed that the concentration of the dissolved carbohydrate is much higher than the concentration of the particulate carbohydrate. This shows that the dissolved carbohydrate is rather resistive to further decay reactions. Owing to the sinking of particulates and the decomposition reactions during the setting, the dissolved carbohydrate is present even in deeper layers. At the same time, it is natural that the concentrations of both the dissolved and the particulate carbohydrates decrease with the a depth. The results of a recent investigation by the present author on the composition of the particulate carbohydrates, the detail of which will be reported later, gives an important suggestion to explain the general pattern of distribution of the two kinds of carbohydrates. The particulate samples collected at different layers at the station 1 in the Izu Shoto areas were subjected to acid hydrolysis and the percentage of D-glucose in the total particulate carbohydrate was determined. The results showed that the percentage regularly decrease with the depth, giving $42.7 \%, 40.8 \%$, $28.6 \%$ and $21.8 \%$ at levels of $20,50,200$ and $500 \mathrm{~m}$ depth respectively. This shows that among many polysaccharides constituting particulates the D-glucose polymer such as starch and glycogen are easily decomposed by the biological hydrolysis, while more resistant polysaccharides can survive to reach deeper layers resulting a less D-glucose enriched particulate carbohydrate.

The higher water temperature and the enrichment of substrates from the decomposition of microflora favor the thrive of flora in the surface and the subsurface layers. Therefore, rates of 
supply and decay of the dissolved carbohydrates are higher there and the balance of two processes decides the concentration of the dissolved carbohydrate. The situation at deeper levels is different. In deeper layer the temperature is lower and some particulate carbohydrates are resistive to microbiological action. This allows the coexistence of the particulate and the dissolved carbohydrates even at the deeper layers.

\section{Summary}

1) The concentration of the dissolved carbohydrate was determined in sea water samples collected at four different regions in the Kuroshio, the Nansei Shoto area, the Izu Shoto area and the areas along JEDS-4 (1961) and JEDS-5 (1962) cruises. The concentration of the dissolved carbohydrate in the surface water ranged from 0.23 to $0.44 \mathrm{mg} / l$ in the Nansei Shoto area and from 0.28 to $0.46 \mathrm{mg} / l$ in the $\mathrm{Izu}$ Shoto area with little horizontal variation. The vertical distribution was also uniform from the surface down to $1,000 \mathrm{~m}$ depth. Below $1,000 \mathrm{~m}$ a slight tendency to decrease with depth was observed in the areas surveyed in JEDS-4 and JEDS-5.

2) The particulate carbohydrate was determined in samples collected from two areas of the Nansei Shoto and the Izu Shoto to be 9.9-30.9 $\mu \mathrm{g} / l$ and $9.9-33.9 \mu \mathrm{g} / l$ respectively. The concentration was high in euphotic zones and and decreased with depth to a $10 \mu \mathrm{g} / l$ at a depth of $500 \mathrm{~m}$ in both areas.

3) The ratio of the dissolved carbohydrate to the particulate carbohydrate was from 10.6 to 26.8 from the surface to the $75 \mathrm{~m}$ depth and increased in deep layers to a value exceeding 35. The ratio is primarily controlled by the variation in the content of the particulate carbohydrate and less affected by the dissolved carbohydrate concentration which was rather uniformly distributed.

\section{Acknowledgements}

The author is much indebted to Dr. K. SUGAWARA, Professor emeritus of Nagoya University for his helpful discussions and criticisms given in the course of this study. Thanks are also due to Drs. T. KoYAmA, Y. KITANO and Y. SAIJO of Nagoya University for their suggestions and encouragements. $\mathrm{He}$ is grateful to Dr. Y. SUGIMURA of Meteorological Research Institute, Tokyo for providing sea water samples collected during the expedition, JEDS-4 (1961) and JEDS-5 (1962).

\section{References}

ANDerson, W. W. and J. W. GeHringer (1958): Physical oceanographic biological and chemical data. South Atlantic Coast of the United States. $\mathrm{M} / \mathrm{V}$ "Theodore" N. Gill Cruise 6 and 8 Spec. Sci. Rep.-Fisheries. No. 265, pp. 1-99; No. 303, pp. 1-227.

ANTIA, A. L. and C. T. LEE (1963): Studies on the determination and differential analysis of dissolved carbohydrate in sea water. Manuscript rep. series No. 168, Fisheries Research Board of Canada.

Collier, A., S. M. RAY, A. M. MAGNITZKY and J. O. BILl (1953): Effect of dissolved organic substances on oyster. U. S. Rep. Int. Fish and Wildlife, Fish Bull., 84, 167-185.

HANDA, N. (1966): Distribution of dissolved carbohydrate in the Indian Ocean. Jour. Oceanogr. Soc. Japan, 22(2), 16-22.

LEWIS, G. J. and N. W. RAKESTRAW (1955): Carbohydrate in sea water. Jour. Marine Res., 14, 253-258.

Masuzawa, J. (1962): Preliminary report of the Japanese Expedition of Deep-Sea, the Fourth Cruise, 1961 (JEDS-4). The Oceanogr. Magazine, 13(2), 119-130.

MENZEL, D. W. (1964): The distribution of dissolved organic carbon in the Western Indian Ocean. Deep-Sea Res., 11, 757-765.

WANGERSKY, D. J. (1952): Isolation of ascorbic acid and rhamnoside from sea water. Science, $115,685$. 


\section{黒潮およびその隣接海域における溶存および浮遊物炭水化物の分布}

\section{半田暢 彦}

要旨 四つの黒潮海域より得られた海水中の溶存および 浮遊物炭水化物量を測定し次のような結果を得た。

1) 南西諸島, 伊豆諸島および本邦東方海域 (JEDS-4 （1961）および JEDS-5 (1962) 等) からの海水中の溶 存炭水化物量はそれぞれ $0.21 \sim 0.43 \mathrm{mg} / l, 0.25 \sim 0.46$ $\mathrm{mg} / l$, および $0.09 \sim 0.43 \mathrm{mg} / l$ の範囲で測定された. 表層水および中層水中の炭水化物量は海域によって多少 の差異のあることが認められたが，一般的には表層から $1,000 \mathrm{~m}$ 層あたりまではほぼ均一に存在し, それ以深の 層では深度とともに減少していく傾向にあった。

2）南西諸島および伊互諸島付近の黒潮海域から得ら れた浮遊物中の炭水化物量はそれぞれ $9.8 \sim 30.0 \mu \mathrm{g} / l$
および $9.9 \sim 33.9 \mu \mathrm{g} / l$ であった．この量は表層水で多 く, 深度とともに減少し, $500 \mathrm{~m}$ 以深ては $10 \mu \mathrm{g} / l$ 前 後の值になった.

3）溶存炭水化物量は浮遊物炭水化物量よりも常に多 く海水中に存在していることが認められた. すなわち前 者の後者に対する比は表層水において約 10 前後であっ たが, 深度とともに增加し, 深層水ではその比が 35 を 越える場合も認められた。

更に, 著者および他の研究者によって従来得られた結 果を用いて, 海水中に打りる溶存扰よび浮遊物炭水化物 の量的関係について多少の討論をする. 